\title{
Determinants of Educational Exclusion of Children: A Study of Southern Punjab,
}

\author{
Pakistan \\ * Zahid Zulfiqar, PhD Scholar \\ ** Dr. Muhammad Shabbir, Assistant Professor (Corresponding Author) \\ *** Dr. Kamran Ishfaq, Associate Professor
}

\begin{abstract}
The current study was conducted in the 3 Districts of Southern Punjab to analyze the parent's attitude towards children's education and teachers related attributes. A sample of 975 household heads were investigated through the interview schedule. It was found that due to poor socioeconomic status, parents involve their children in livestock activities due to poverty. Parents do not know the importance of education due to their illiteracy. Teachers, related issues were also explored like shortage of teachers, usage of bad language by teachers, exercise of corporal punishment, and late join of school by teachers as well. These above issues negatively affected the educational inclusion of children in southern Punjab, Pakistan. Based on results, the researcher recommended that the government should have arranged professional and focus for the scholarships to the needy children and arrange seminars to motivate the community towards children education.
\end{abstract}

Keywords: Determinants, Exclusion of children, Education, South Punjab.

Introduction

Education is the fundamental, compulsory, and universal right of everyone without any discrimination which guaranteed peace, prosperity, and development in society. Education developed the rational and positive thinking among the people. The Universal Declaration of Human Rights 1948 Article 26 (1) and the constitution of Pakistan 1973, Article 25-A declares primary education as obligatory for every child without any distinction. The Millennium Development Goals (Goal 2) also emphasized the provision of primary education "to getting achieve equality in access to primary education for all males and females by 2015" (UNESCO, 2010). There were worldwide 29.1 million children who were excluded from basic education instead of national, international and Islamic obligation. It was reported that 10.3 percent of children were excluded in South Asia and 22.9 percent of children of developing countries were excluded from primary education (UNESCO, 2018).

\section{Structural Condition of primary Education in Pakistan}

Pakistan is a developing country and its majority laid hand to mouth. In this situation, unfortunately, 23 percent of children did not have access to basic education in Pakistan (NEMIS, 2017). It was highlighted by Pakistan Education Statistics 2015-16 (2017) that there were 1979595 boys and 3046373 girls of 5-9 years old who had been excluded from basic primary education in Pakistan. The data also represented the downward vertical mobility of children enrolment in Pakistan. There were 133347 public schools in 2011-12 whereas in 2014-15 these were 121674 public schools. It's a question mark on the educational planning and management of Pakistan that instead of increasing the Public primary schools 11673 public schools were closed within five years. These irrational changes strongly affected the enrolment of children. In the year of 2011-12, there were 121674 boys and 6215734 girls enrolled in the public schools but unfortunately, after five years instead of increasing the enrolment of the boys was 6155847 and the girls enrolment was 4932915 . There were a total of 331451 public primary school teachers in 2011-12 and with the decrease of 14188 teachers total teachers remained 317263 in 2015-16. These managerial gaps played a negative role in the educational inclusion of children in Pakistan. In this, it could be argued that there was a strong relationship between the availability of the public schools, children enrolment, and availability of the teachers in the government primary schools. Increasing the number of public primary schools and

\footnotetext{
* Department of Sociology, Government College University Faisalabad Email: ranazahidzulfiqar@gmail.com ** Department of Sociology, Government College University Faisalabad Email: drmshabbir@ gcuf.edu.pk

*** Bahauddin Zakariya University Multan, Pakistan Email: dr.kamran@bzu.edu.pk
} 
teachers would increase the enrolment of the children (Porter \& McKibbin, 1988). Teachers' absenteeism was also a barrier to the educational inclusion of children (Manacorda, 2012).

Many other factors played a negative role in the inclusion of primary-school-age children in Pakistan. The low qualification of the teachers also played a negative role in the inclusion of children. It was highlighted by Pakistan Education Statistics 2015-16 (2017) that there were 370 public teachers whose qualification was middle, 47683 teachers were matriculation qualified, 55596 teachers were working as public school teachers whose qualification was intermediate and there were only $68 \mathrm{Ph} . \mathrm{D}$. government primary school teachers throughout Pakistan. In this way, we could state how it could be possible that these less qualified (middle, matriculation and intermediate) teachers could teach properly. The curriculum of the primary classed was updated and the less qualified teachers could not teach properly. It was social as well as religious responsibility of the state to hire well qualified and trained teachers for the quality enhancement of the children.

It was reported that the overall literacy rate of Pakistan was 60 percent; 63 percent in Punjab; 60 percent in Sindh, 53percent in Khyber Pakhtunkhwa and Balochistan had the lowest literacy rate of ten years and above with 44 percent literacy rate (Pakistan Social and Living Standards Measurement 2014-15, 2016). The literacy rate of Punjab was quite better as compared to other provinces of Pakistan but it was also not satisfactory because the set target of Millennium Development Goals was to achieve a 100 percent literacy rate. The province of Punjab had a geographical divide of upper Punjab and southern Punjab. The educational status of the upper Punjab was better than that of southern Punjab. The majority of the districts were agrarian and the government did not focus to uplift the educational structure of these areas. The current study focused to study the household head, socioeconomic status, parents' attitude towards children education, and teachers attributes.

\section{Methodology}

The current study was conducted in the 3 Districts "Multan, Dera Ghazi Khan and Bahawalpur" Southern Punjab, Pakistan. The researcher used the multistage random sampling in which firstly three divisions were selected (Bahawalpur, Dera Ghazi Khan and Multan) then reselected the two tehsils from each district and at the end, two Union Councils were randomly selected from each tehsil (Punjab Bureau of Statistics, 2016). The researcher selected 975households in which 5-9 years old children were available. The researcher conducted the household survey from the household heads because household heads were the main stakeholders of the family. The researcher made two categories, the households in which 5-9 years old children were excluded (600) from primary education and the household where 5-9 years old children were not excluded from primary education (375). The interview schedule was used as a tool for data collection because the majority of the respondents were illiterate. The data were analyzed using the Statistical Package for Social Sciences (SPSS) version 19. The researcher used descriptive statistics which included frequency, percentage, mean, standard deviation, and inferential statistics.

Table Number 1: Demographic characteristics and Educational Exclusion of Children

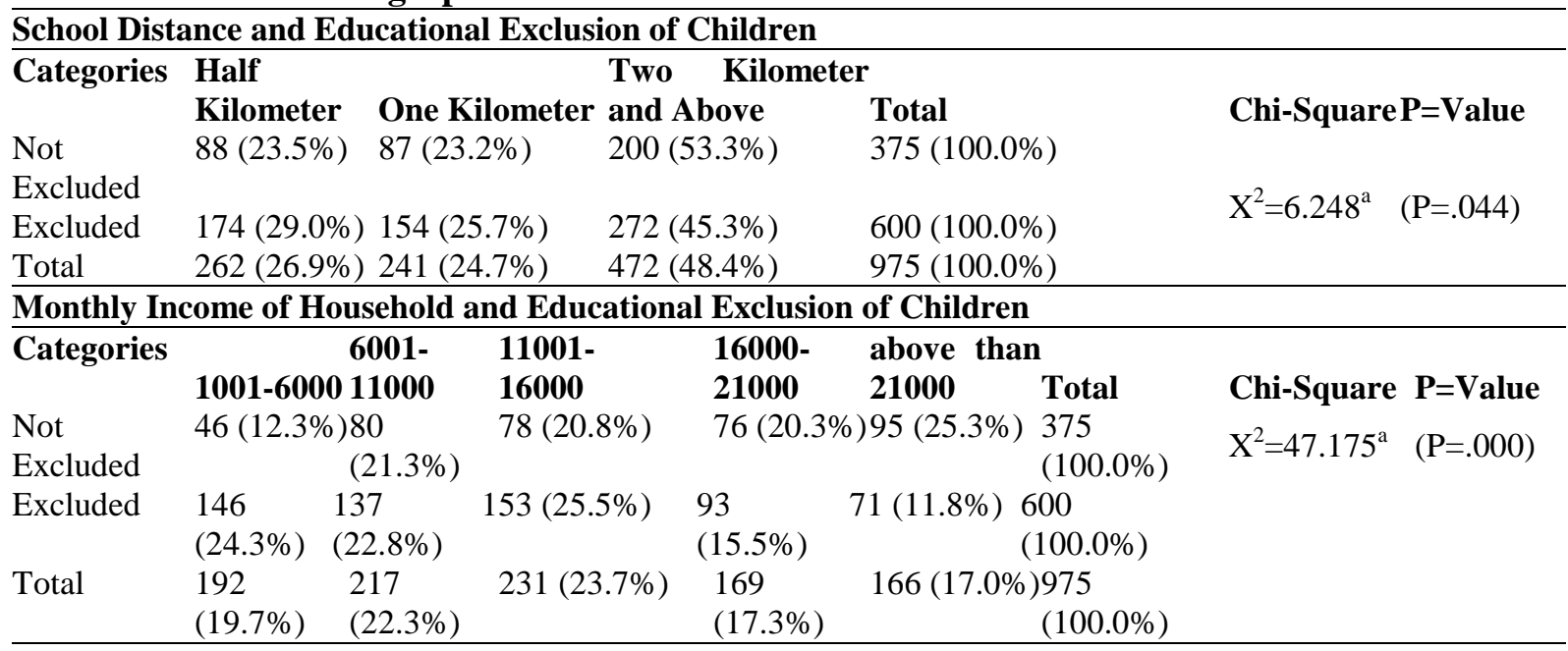

Children Involvement in the Livestock and Educational Exclusion of Children

\begin{tabular}{llllll}
\hline Categories & Yes & No & Total & Chi-Square & P=Value \\
\hline Not Excluded & $169(45.1 \%)$ & $206(54.9 \%)$ & $375(100.0 \%)$ & $\mathrm{X}^{2}=3.124$ & $(\mathrm{P}=.045)$
\end{tabular}




\begin{tabular}{|c|c|c|c|c|c|}
\hline \multicolumn{6}{|c|}{ School Distance and Educational Exclusion of Children } \\
\hline \multirow[t]{2}{*}{ Categories } & Half & & Two Kilo & & \multirow{3}{*}{ Chi-Square $P=$ Value } \\
\hline & Kilometer & One Kilometer & and Above & Total & \\
\hline Not & $88(23.5 \%)$ & $87(23.2 \%)$ & $200(53.3 \%)$ & $375(100.0 \%)$ & \\
\hline Excluded & & & & & \multirow{5}{*}{$\mathrm{X}^{2}=6.248^{\mathrm{a}} \quad(\mathrm{P}=.044)$} \\
\hline Excluded & $174(29.0 \%)$ & $154(25.7 \%)$ & $272(45.3 \%)$ & $600(100.0 \%)$ & \\
\hline Total & $262(26.9 \%)$ & $241(24.7 \%)$ & $472(48.4 \%)$ & $975(100.0 \%)$ & \\
\hline Excluded & $236(39$ & $3 \%) \quad 364(60$. & $.7 \%)$ & $600(100.0 \%)$ & \\
\hline Total & $405(41$. & $570(58$ & $3.5 \%)$ & $975(100.0 \%)$ & \\
\hline
\end{tabular}

The researcher asked the different questions to know the causes of the educational exclusion of school-age children in Southern Punjab, Pakistan. The first question was "Distance of the school". It was reported by 262 respondents among 975 respondents that the distance of the school from their house was half a kilometer; 241 respondents' home and school distance was about one kilometer, whereas $472(48.4 \%)$ respondents school and home distance was two or more kilometers. The study showed a significant relationship $\left(\mathrm{X}^{2}=6.248^{\mathrm{a}}\right),(\mathrm{P}=.044)$ between the public school distance and the educational exclusion of the children. The economic resources and educational exclusion of children was also checked by asking the monthly income of the household head. It was found that there were $192(19.7 \%)$ households whose monthly income was 1001-6000; 217 (22.3\%) households whose monthly income was 6001- 11000; 231 (23.7\%) whose monthly income was 11001-16000; 169 (17.3\%) households monthly income was 16001-21000 and there were 166 (17.0\%) respondents whose monthly income was more than 21000 . The majority of $231(23.7 \%)$ of the respondents monthly income was 11001-16000. Present study also found a significant relationship $\left(X^{2}=47.175^{\mathrm{a}}\right)$, $(\mathrm{P}=.000)$ between the household monthly income and the educational exclusion of the children. Southern Punjab is very much enriched regarding Agriculture and due to poverty and lack of educational importance parents may involve their children in agriculture and taming the animals. The researcher asked the question from the respondents about their children involved in the livestock activities. It was found that $405(41.5 \%)$ respondents were agreed that they involved their children in the livestock activities, whereas 570(58.5\%) respondents denied that their children were not involved in the livestock activities. There was a significant relationship $\left(\mathrm{X}^{2}=3.124\right),(\mathrm{P}=.045)$ between the availability of livestock in the home and the educational exclusion of the children.

\section{Table Number 2: Parents Attitude and Educational Exclusion of Children}

\begin{tabular}{|c|c|c|c|c|c|c|c|}
\hline \multicolumn{7}{|c|}{$\begin{array}{l}\text { Education for Daughters' is Equally Important as for Sons and Educational }{ }_{\text {Chi-Square }} \\
\text { Exclusion of Children }\end{array}$} & \multirow{2}{*}{$P=$ Value } \\
\hline Category & $\begin{array}{l}\text { Strongly } \\
\text { Aoree }\end{array}$ & Aoree & & Disaoree & $\begin{array}{l}\text { Strongly } \\
\text { Disagree }\end{array}$ & & \\
\hline Not & $\begin{array}{l}\text { Agree } \\
28(7.5 \%)\end{array}$ & $71(18.9 \%)$ & $99(26.4 \%$ & $99(26.4 \%)$ & $78(20.8 \%)$ & $375(100.0 \%)$ & \\
\hline $\begin{array}{l}\text { Excluded } \\
\text { Excluded }\end{array}$ & $7(1.2 \%)$ & $25(4.2 \%)$ & $35(5.8 \%)$ & $\begin{array}{l}259 \\
(43.2 \%)\end{array}$ & $274(45.7 \%$ & 6)600(100.0\%) $X^{2}=210.567^{a}$ & $(\mathrm{P}=.000)$ \\
\hline Total & $35(3.6 \%)$ & $96(9.8 \%)$ & $\begin{array}{l}134 \\
(13.7 \%)\end{array}$ & $\begin{array}{l}358 \\
(36.7 \%)\end{array}$ & $352(36.1 \%$ & 6)975 (100.0\%) & \\
\hline
\end{tabular}

Families with Limited Finance resources Give Priority to Sons' Education Not Daughter's Education and Educational Exclusion of Children

\begin{tabular}{|c|c|c|c|c|c|c|}
\hline Not & $31(8.3 \%)$ & $45(12.0 \%$ & 114 & 128 & $57(15.2 \%) 375(100.0 \%)$ & \\
\hline Excluded & & & $(30.4 \%)$ & $(34.1 \%)$ & & \\
\hline Excluded & $10(1.7 \%)$ & $44(7.3 \%)$ & $\begin{array}{l}111 \\
(18.5 \%)\end{array}$ & $\begin{array}{l}273 \\
(45.5 \%)\end{array}$ & $162(27.0 \%) 600(100.0 \%) X^{2}=65.126^{a}$ & $(\mathrm{P}=.000)$ \\
\hline Total & $41(4.2 \%)$ & $89(9.1 \%)$ & $\begin{array}{l}225 \\
(23.1 \%)\end{array}$ & $\begin{array}{l}401 \\
(41.1 \%)\end{array}$ & $219(22.5 \%) 975(100.0 \%)$ & \\
\hline
\end{tabular}

There Must be Separate Schools for Males and Females and Educational Exclusion of Children

\begin{tabular}{lllllll}
\hline $\begin{array}{l}\text { Not } \\
\text { Excluded }\end{array}$ & $42(11.2 \%) 20(5.3 \%)$ & $43(11.5 \%)$ & 150 & $120(32.0 \%) 375(100.0 \%)$ \\
Excluded & $8(1.3 \%)$ & $10(1.7 \%)$ & $23(3.8 \%)$ & $\begin{array}{l}(40.0 \%) \\
(30.8 \%)\end{array}$ & $374(62.3 \%) 600(100.0 \%)$ \\
& & & & & \\
Total & $50(5.1 \%)$ & $30(3.1 \%)$ & $66(6.8 \%)$ & $\begin{array}{l}335 \\
(34.4 \%)\end{array}$ & $494(50.7 \%) 975(100.0 \%)$ & \\
& & & $\left(34.307^{\mathrm{a}}\right.$ & $(\mathrm{P}=.000)$ \\
\hline
\end{tabular}


The researcher examined the parents' attitudes regarding children education by asking different questions. The first question asked by the researcher that "Education for Daughters' was Equally Important as for Sons". It was reported by $35(3.6 \%)$ respondents that they were strongly agreed; about 96 (9.8\%) respondents were agreed; 134 (13.7\%) respondents were Neutral; 358 (36.7\%) respondents disagreed and $352(36.1 \%)$ respondents were strongly disagreed that education for daughter was not equally important as compared to sons. There was significant a relationship $\left(\mathrm{X}^{2}=210.567^{\mathrm{a}}\right),(\mathrm{P}=.000)$ between the parents' attitude that education for daughters' was equally important as for sons and the educational exclusion of the children. To check the gendered attitude of the parents the researcher asked that "Families with limited financial resources gave priority to sons' education, not daughter's education?" It was found that $41(4.2 \%)$ of the respondents were Strongly Agreed; about $89(9.1 \%)$ respondents were Agreed; the $225(23.1 \%)$ respondents were Neutral; 219 $(22.5 \%)$ were strongly disagreed and majority $401(41.1 \%)$ of the respondents disagreed that limited financial resources families gave priority to sons' education, not daughter education. There was a significant relationship $\left(\mathrm{X}^{2}=65.126^{\mathrm{a}}\right),(\mathrm{P}=.000)$ between the parents' attitude that limited financial resources families gave priority to sons' education, not daughter's education, and the educational exclusion of the children. The researcher asked the question "There must be separate schools for males and females" to examine the traditional influence on the parents. It was found that the majority of $494(50.7 \%)$ of the households were strongly disagreed that there must be separate schools for male and female children. There was a significant relationship $\left(\mathrm{X}^{2}=121.307^{\mathrm{a}}\right),(\mathrm{P}=.000)$ between the parents' attitude that there must be separate schools for males and females and the educational exclusion of the children.

Table Number 4: Teachers characteristics and exclusion of children

\begin{tabular}{|c|c|c|c|c|c|c|c|c|}
\hline \multicolumn{9}{|c|}{ Abusive Language of the Teachers and Educational Exclusion of Children } \\
\hline Categories & Strongly & & & & Strongly & & & \\
\hline & Agree & Agree & Neutral & Disagree & Disagree & Total & Chi-Square & $P=$ Value \\
\hline Not & $115(30.7 \%)$ & $124(33.1 \%)$ & $72(19.2 \%)$ & $50(13.3 \%)$ & $14(3.7 \%)$ & & & \\
\hline Excluded & & & & & & $(100.0 \%)$ & & \\
\hline Excluded & $10(1.7 \%)$ & $68(11.3 \%)$ & $200(33.3 \%)$ & $213(35.5 \%)$ & $109(18.2 \%$ & $\begin{array}{l}600 \\
(100.0 \%)\end{array}$ & $X^{2}=303.400^{\mathrm{a}}$ & $(\mathrm{P}=.000)$ \\
\hline Total & $125(12.8 \%)$ & $192(19.7 \%)$ & $272(27.9 \%)$ & $263(27.0 \%)$ & $123(12.6 \%$ & $\begin{array}{l}975 \\
(100.0 \%)\end{array}$ & & \\
\hline
\end{tabular}

Teachers giving Corporal Punishment and Educational Exclusion of Children

\begin{tabular}{llllllll}
\hline $\begin{array}{l}\text { Not } \\
\text { Excluded } \\
\text { Excluded }\end{array}$ & $90(24.0 \%)$ & $121(32.3 \%)$ & $75(20.0 \%)$ & $69(18.4 \%)$ & $20(5.3 \%)$ & 375 \\
& & & & & & $(100.0 \%)$ & \\
Total & $93(9.5 \%)$ & $170(17.4 \%)$ & $238(24.4 \%)$ & $360(36.9 \%)$ & $114(11.7 \%)$ & 975 &
\end{tabular}

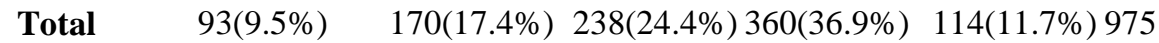

\begin{tabular}{|c|c|c|c|c|c|c|}
\hline \multicolumn{7}{|c|}{ Teachers Coming Late in the School and Educational Exclusion of Children } \\
\hline Not & $87(23.2 \%)$ & $144(38.4 \%)$ & $80(21.3 \%) \quad 46(12.3 \%)$ & $18(4.8 \%)$ & 375 & \\
\hline Excluded & & & & & $(100.0 \%)$ & \\
\hline Excluded & $19(3.2 \%)$ & $62(10.3 \%)$ & $215(35.8 \%) 200(33.3 \%)$ & $104(17.3 \%)$ & $\begin{array}{l}600 \\
(100.0 \%)\end{array}$ & $\mathrm{X}^{2}=256.827^{\mathrm{a}} \quad(\mathrm{P}=.000)$ \\
\hline Total & $106(10.9 \%)$ & $206(21.1 \%)$ & $295(30.3 \%) 246(25.2 \%)$ & $122(12.5 \%)$ & 975 & \\
\hline
\end{tabular}

$(100.0 \%)$

\begin{tabular}{|c|c|c|c|c|c|}
\hline \multicolumn{6}{|c|}{ Shortage of Teachers and Educational Exclusion of Children } \\
\hline Not & $57(15.2 \%)$ & $120(32.0 \%)$ & 61(16.3\%) $92(24.5 \%)$ & $45(12.0 \%) \quad 375$ & \\
\hline Excluded & & & & $(100.0 \%)$ & \\
\hline Excluded & $9(1.5 \%)$ & $38(6.3 \%)$ & $161(26.8 \%) 239(39.8 \%)$ & $\begin{array}{r}153(25.5 \%) 600 \\
(100.0 \%)\end{array}$ & $X^{2}=205.738^{a} \quad(P=.000)$ \\
\hline Total & $66(6.8 \%)$ & $158(16.2 \%)$ & $222(22.8 \%) 331(33.9 \%)$ & $\begin{aligned} 198(20.3 \%) & 975 \\
& (100.0 \%)\end{aligned}$ & \\
\hline
\end{tabular}

The researcher also examined the teacher's attributes of primary schools by asking different questions from the respondents. It was asked that "did the teachers use the abusive language?". It was found that 125(12.8\%) respondents were Strongly Agreed; 192(19.7\%) were Agreed; 263(27.0\%) Disagreed; 123(12.6\%) Strongly Disagreed and majority 272(27.9\%) of the respondents were Neutral that primary school teachers used the teachers use the abusive language. There was a significant 
relationship $\left(\mathrm{X}^{2}=303.400^{\mathrm{a}}\right),(\mathrm{P}=.000)$ between the teachers' abusive language and the educational exclusion of the children. It was asked that "Teachers giving Corporal Punishment to the students?" It was found that 93(9.5\%) respondents were Strongly Agreed; $170(17.4 \%)$ were Agreed; $238(24.4 \%)$ of the respondents were Neutral; 360(36.9\%) were Disagreed and 114(11.7\%) Strongly Disagreed and majority that primary school teachers used the teachers' giving corporal Punishment to the student. There was a significant relationship $\left(\mathrm{X}^{2}=293.037^{\mathrm{a}}\right),(\mathrm{P}=.000)$ between the corporal punishment and the educational exclusion of the children.

The next was related to the formal school time table followed by the primary school teachers. It was found that 106(10.9\%) respondents were Agreed; about 206(21.1\%) respondents Strongly Disagreed; majority 295(30.3\%) of the respondents were Neutral; 246(25.2\%) respondents Disagreed and $122(12.5 \%)$ of the respondents Strongly Disagreed that primary school teachers were coming late in the schools. There was a significant relationship $\left(\mathrm{X}^{2}=256.827^{\mathrm{a}}\right),(\mathrm{P}=.000)$ between the teachers' coming late in the school and the educational exclusion of the children. The next question was about the "Teachers shortage in the government primary schools". It was found that $66(6.8 \%)$ respondents were Agree; about 158(16.2\%) respondents were Strongly Agreed; 222(22.8\%) respondents were Neutral; 331(33.9\%) respondents were Disagree and 198(20.3\%) respondents Strongly Disagreed that there was a shortage of primary school teachers. There was a significant relationship $\left(X^{2}=205.738^{\mathrm{a}}\right)$, $(\mathrm{P}=.000)$ between the shortage of teachers and the educational exclusion of the children.

\section{Discussion}

There were different determinants of educational exclusion of the children in Southern Punjab among them school distance was one of the important determinants that negatively affected the children enrolment in the school. The study showed a significant relationship $\left(\mathrm{X}^{2}=6.248^{\mathrm{a}}\right),(\mathrm{P}=.044)$ between the public school distance and the educational exclusion of the children. Zulfiqar and Chaudhry(2019) conducted the qualitative research and highlighted that children were excluded from basic education due to the non-provision of the pick and drop service. The long-distance from home to school negatively affected the children (girls) education. Imdad (2019) highlighted that the children faced different serious criminal issues in Pakistan in the year of 2018. His study reported that about 3832 children reported who faced harassment; 452 cases were of missing children, 345 were attempted to rapes and 156 cases were of gang rape. The rural children were more sexually abused than urban children. These bad incidents also stopped the parents to send their children to the schools' distance of which far from their homes.

The economic resources also played a vital role in the inclusion or exclusion of children in primary education. The present study also found a significant relationship $\left(\mathrm{X}^{2}=47.175^{\mathrm{a}}\right),(\mathrm{P}=.000)$ between the household monthly income and the educational exclusion of the children. Pakistan Social and Living Standards Measurement 2014-15(2016) highlighted that at least half of the children from the poorest households aged five to nine were excluded from basic education; whereas only $17 \%$ children were from wealthy families. It was also highlighted that overall only $62 \%$ of children were getting the education to some extent and others were generally excluded from the education system in Pakistan (Pakistan Social and Living Standards Measurement, 2014). The above-mentioned situation of children exclusion in education was showing the diverse impact of poverty on children education. Another study also verified the results that there was a significant relationship $(\mathrm{P}=0.046)$ between the income of the household and the educational attainment of the children (Hashmi, 2009).The study conducted by Zulfiqar; Shabbir and Ishfaq(2019)showed that parents were agreed (4.1600) that they faced economic constraints to educated their children. The children of rural and marginalized areas faced more transportation difficulties (Lloyd, 2005; Allais, 2007; Senadza, 2012; Farrah, 2013).In our study, there was a significant relationship $\left(\mathrm{X}^{2}=3.124\right),(\mathrm{P}=.045)$ between the availability of livestock in the home and the educational exclusion of the children.

In our study, there was significant a relationship was found $\left(\mathrm{X}^{2}=210.567^{\mathrm{a}}\right),(\mathrm{P}=.000)$ between the parents' attitude that education for daughters' was equally important as for sons and the educational exclusion of the children. Majority 429(44.0\%) of the respondents were strongly disagreed that education for daughters' was equally important as for sons. A previous study also highlighted that 60 percent of respondents responded that the daughter should have to stay at home and perform domestic works (Hashmi, 2009). The current research showed that there was a significant relationship was found $\left(\mathrm{X}^{2}=65.126^{\mathrm{a}}\right),(\mathrm{P}=.000)$ between the parents' attitude that limited financial resources families gave priority to sons' education, not daughter's education and the educational 
exclusion of the children. It was highlighted by Hashmi(2015)that 52 percent of household heads preferred male children over female children. Moreover, another study conducted in southern Punjab, Pakistan also verified the results that there were $(60.5 \%)$ teachers, $(52 \%)$ students and (17\%) parents agreed that gender discrimination was the key obstacle in the educational inclusion of children (Sattar, Yasin \& Afzal, 2012). It was also found that if the poor households got a chance to educate their children, sons were their choice because they considered that sons would look after them in their old age, and daughters would leave home after marriage (Oxaal, 1997; Hashmi, 2015).

It was found in our research that there was a significant relationship $\left(\mathrm{X}^{2}=121.307^{\mathrm{a}}\right),(\mathrm{P}=.000)$ between the parents' attitude that there must be separate schools for males and females and the educational exclusion of the children.It was reported that $(27.5 \%)$ teachers, $50.5 \%$ of students, and $(35.5 \%)$ parents agreed that patriarchal norms were hindering the parents to send their daughters in the schools in South Punjab, Pakistan (Sattar, Yasin \& Afzal, 2012).

The results of our study showed a significant relationship $\left(\mathrm{X}^{2}=303.400^{\mathrm{a}}\right),(\mathrm{P}=.000)$ between the teacher's abusive language and the educational exclusion of the children. It could be stated that poor and excluded children faced more victimized by teachers' harshness and bad behavior due to their weak social identity. It was estimated by the Department for International Development (2005) that approximately 891 million individuals faced social exclusion in the name of their ethnic, religious, and religious identity. There was a significant relationship was found $\left(X^{2}=293.037^{\mathrm{a}}\right)$, $(\mathrm{P}=.000)$ between the corporal punishment and the educational exclusion of the children. The results showed that corporal punishment was also one of the important reasons for children exclusion from primary education in south Punjab.

In our study, it was showed a significant relationship was found $\left(\mathrm{X}^{2}=256.827^{\mathrm{a}}\right),(\mathrm{P}=.000)$ between the teachers' coming late in the school and the educational exclusion of the children. It could be argued that time is money and more precious thing in this world. Fobih et al. (1999) found that 85 $\%$ teachers reached late (from 5 to 90 minutes) in the school, in this way teachers were playing an important role in the exclusion of children because teachers wasted the teaching time and the students also came late and were irregular due to the negligence of the teachers. In this way, it could be argued that teachers' lateness badly affected the children education and it compelled the parents to exclude their children from basic education. There was a significant relationship $\left(X^{2}=205.738^{a}\right),(P=.000)$ between the shortage of teachers and the educational exclusion of the children. It could be argued that the shortage of teachers negatively affected the enrolment of the children as the previous data showed that in the year of 2011-12 there 121674 boys and 6215734 girls were enrolled in the public schools but unfortunately, after five years instead of an increase of the enrollment the enrolment of the boys was 6155847 and the girls enrolment in the public schools was 4932915 . There were a total of 331451 public primary school teachers in 2011-12 and with the decrease of 14188 total teachers were 317263 in 2015-16. In this, it could be argued that there was a strong relationship between the shortage of teachers and low children enrolment in government primary schools (Pakistan Education Statistics 2015-16, 2017).

\section{Conclusion}

It could be summarized that due to the active and passive exclusion, the people of Southern Punjab were excluded from the necessities of life. It was found that People of the studied districts were excluded from the visionary future of their children due to the low socio-economic status. They did not have an enlightened vision regarding education. It not only affected the children's future but also lay down the progress and prosperity of the society as a whole. It was concluded that children of the research areas were facing different problems in educational inclusion like the distance from school to home was one important factor with two or more kilometers away. This shows the strong relationship between the longer school distances and the educational exclusion of primary school children. The low economic status of the parents was another determinant of children exclusion in primary education. The people of Southern Punjab are excluded from the mainstream and the majority of the people had a low economic status that becomes the reason for the educational exclusion of children. It was also included that children's involvement in the livestock was another cause of educational exclusion in South Punjab. The researcher also checked the parents' attitude regarding children education where the respondents had a gendered attitude and were biased regarding daughters' education. Teachers related issues were also found in the research, like shortage of teachers, usage of bad language by teachers, giving corporal punishment to the students and teachers coming late as 
well. These above issues negatively affected the educational inclusion of children in southern Punjab, Pakistan. Based on findings it is recommended that the government of Pakistan should have to do socio-economic development of south Punjab for the social inclusion of people. The government should have to increase the educational budget and construct new separate boys' and girls' primary schools to tackle the educational exclusion of children in South Punjab. The government should have to recruit new well-qualified teachers and give them professional and ethical training to tackle the biased and non-professional attitude of the primary school teachers.

\section{Recommendations}

It is recommended that the government of Pakistan should have to focus the marginalized areas by providing scholarships to the needed children and organize the different seminars in these areas to motivate the community towards children education and build gender sensitivity. The government should have to hire more well-qualified teachers and give them Islamic training.

\section{References}

Allais, F. B. (2007). Children's work in Angola: an overview. University of Rome" tor Vergata.

Annual Status of Education Report (ASER) 2011. (2012). Lahore, Pakistan.

Bilquees, F., \& Saqib, N. (2004). Drop-out rates and inter-school movements: Evidence from panel data. Islamabad: Pakistan Institute of Development Economics.

Chaudhry, I. S., \& Rahman, S. (2009). The impact of gender inequality in education on rural poverty in Pakistan: an empirical analysis. European Journal of Economics, Finance and Administrative Sciences, 15(1), 174-188.

Chege, F., \& Sifuna, D. N. (2006). Girls' and women's education in Kenya. Gender Perspectives and trends, 91, 86-90.

Colclough, C., Al-Samarrai, S., Rose, P., \& Tembon, M. (2004). Achieving schooling for all in Africa: costs, commitments, and gender. Ashgate Press.

Department for International Development (DFID). (2005).Reducing poverty by tackling social exclusion.

Dollar, D., \& Kraay, A. (2000). Growth is good for the poor."World bank. Development Research Group, Washington, DC Processed.

Farrah, R. Y. (2013). A study of the indigenous minorities of Somaliland: Focus on barriers to education. Alliant International University.

Filmer, D. (2007). If you build it, will they come? School availability and school enrolment in 21 poor countries. The Journal of Development Studies, 43(5), 901-928.

Fobih, D., Akyeampong, K. A., \& Koomson, A. (1999). Ghana primary school development project: Final evaluation of project performance. Accra: Ministry of Education.

Hashmi, N. (2009). FEMALE EDUCATIONAL ATTAINMENT WITHIN SOCIO-ECONOMIC AND CULTURAL CONTEXT (Doctoral dissertation, University of Agriculture, Faisalabad, Pakistan).

Huisman, J., \& Smits, J. (2009). Effects of household-and district-level factors on primary school enrollment in 30 developing countries. World Development, 37(1), 179-193.

Imdad. (2019, June 08). Over 10 children abused every day in Pakistan in 2018: Sahil report. Dawn. Pakistan.

Kenyon, S. (2011). Transport and social exclusion: access to higher education in the UK policy context. Journal of Transport Geography, 19(4), 763-771.

Khanam, R., \& Ross, R. (2011). Is child work a deterrent to school attendance and school attainment?. International Journal of Social Economics.

Klasen, S. (2002). Low schooling for girls, slower growth for all? Cross-country evidence on the effect of gender inequality in education on economic development. The World Bank Economic Review, 16(3), 345-373.

Lewis, M. A., \& Lockheed, M. E. (2007). Social exclusion: The emerging challenge in girls' education. Washington $D C$.

Lloyd, C. B., \& Grant, M. J. (2005). Growing up in Pakistan: the separate experiences of males and females. The changing transitions to adulthood in developing countries: selected studies. Washington, DC: CPOP, 320Á66.

Manacorda, M. (2012). The cost of grade retention. Review of Economics and Statistics, 94(2), 596606. 
National Education Management Information System (NEMIS). (2017). Pakistan Education Statistics 2015-16, Government of Pakistan, Islamabad.

Oxaal, Z. (1997). Education and poverty: A gender analysis (Vol. 53). Sussex: Institute of Development Studies at the University of Sussex.

Pakistan Education for All, Review report 2015. (2014). Ministry of Education, Trainings and Standards in Higher Education Academy of Educational Planning and Management Islamabad, Pakistan.

Pakistan Education Statistics 2015-16. (2017). National Education Management Information System, Pakistan.

Pakistan Education Statistics 2015-16. (2017). National Education Management Information System, Academy of Educational Planning and Management Ministry of Federal Education \& Professional Training Islamabad, Pakistan.

Pakistan Social and Living Standards Measurement Survey 2014-15. (2016). National / Provincial /District. Government of Pakistan Statistics Division, Pakistan Bureau of Statistics Islamabad, Pakistan.

Purewal, N., \& Hashmi, N. (2015). Between returns and respectability: parental attitudes towards girls' education in rural Punjab, Pakistan. British Journal of Sociology of Education, 36(7), 977-995.

Sathar, Z. A., \& Lloyd, C. B. (1994). Who gets primary schooling in Pakistan: Inequalities among and within families. The Pakistan Development Review, 103-134.

Sattar, T. (2012). A sociological analysis of stumbling blocks in the structure of the education sector: A case of affiliated schools from board of intermediate and secondary education of Multan district (Pakistan). International Journal of Humanities and Social Science, 2(5), 96-110.

Sattar, T., Yasin, G., \& Afzal, S. (2012). Socio-cultural and economic impediments of inequality in the provision of educational right to female: A case of Southern Punjab (Pakistan). International Journal of Human Resource Studies, 2(1), 122.

Sen, A. (2000). Social exclusion: Concept, application, and scrutiny.Harvard University Social Development Papers No. 1 Office of Environment and Social Development Asian Development Bank.

Senadza, B. (2012). Education inequality in Ghana: gender and spatial dimensions. Journal of Economic Studies.

Situation Analysis of Children in Pakistan (SitAn). (2017). United Nations Children's Fund (UNICEF), Pakistan.

Tesema, M. T., \& Braeken, J. (2018). Regional inequalities and gender differences in academic achievement as a function of educational opportunities: Evidence from Ethiopia. International Journal of Educational Development, 60, 51-59.

UNESCO Institute for Statistics (UIS). (2018). One in Five Children, Adolescents, and Youth is Out of School. Fact Sheet No. 48. Montreal.

UNESCO Institute for Statistics (UIS). (2018). One in Five Children, Adolescents, and Youth is Out of School. Fact Sheet No. 48. Montreal:

United Nations Educational, Scientific, and Cultural Organization (UNESCO). (2010). Education for All Global Monitoring Report 2010: Reaching the Marginalized. UNESCO Publishing, Paris, France.

Zulfiqar, Z. \& Shabbir, M. (2019). The Sociological Study of Educational Exclusion of School-Age Children in South Punjab (Pakistan). Pakistan Journal of Social Sciences (PJSS), 39(3).pp. 785-794

Zulfiqar, Z., Shabbir, M., \& Ishfaq, K. (2019). A Sociological Study of Contributing Factors of Educational Exclusion of Children in Southern Punjab, Pakistan. Pakistan Social Sciences Review (PSSR) 3(2).pp. 282-292 